\title{
IMPLEMENTASI ASAS KEPASTIAN HUKUM YANG BERKEADILAN BERDASAR CITA HUKUM BANGSA INDONESIA (Kajian Putusan Pengadilan Negeri Banyumas tentang kasus mbah Minah)
}

\author{
Oleh : Iskandar Wibawa \\ Email: iskandar.wibawa@yahoo.com
}

\begin{abstract}
Legality is one basic of penal law beside culpability in deciding the punishment. Legality is often perceived similar to law enforcement. According to Article 1 (1) of the Penal Law $(K U H P)$, the law refers to written law. In fact, there is also living law mentioned in the Constitution. This kind of situation often causes the judge decision fails to meet social justice since the decision is merely based on formal law and neglected material law, such as in the case of Minah in Banyumas Court. Thus, progressive approach is necessitated in order to understand legality both in formal and material law in accordance with national legal ideals, Pancasila.
\end{abstract}

Keywords: legality, law, living law, legal ideals

\section{A. PENDAHULUAN}

Pembaharuan Hukum Indonesia dimulai sejak diproklamasikannya kemerdekaan bangsa Indonesia pada tanggal 17 Agustus 1945. Pembukaan Undang Undang Dasar 1945 alinea 3 menyatakan bahwa kemerdekaan bangsa Indonesia merupakan berkah dan rahmat Allah Yang Maha Kuasa serta adanya keinginan luhur dari bangsa Indonesia untuk berkehidupan kebangsaan yang bebas. Keinginan luhur untuk berkehidupan kebangsaa yang bebas itu dicapai dengan membentuk pemerintah Negara Indonesia yang disusun dalam Undang Undang Dasar. Dengan demikian maka cita-cita atau keinginan luhur bangsa Indonesia adalah terwujudnya kehidupan berbangsa yang 
bebas dalam suatu keteraturan berbingkai Undang Undang Dasar.

Undang-Undang Dasar merupakan hukum dasar (konstitusi) yang bweperan sebagai landasan tertib hukum suatu negara. Dengan demikian maka kehidupan kebangsaan yang bebas sebagaimana diamanatkan dalam Pembukaan Undang Undang Dasar 1945 adalah "kehidupan kebangsaan bebas berlandaskan pada tertib hukum".

Undang-Undang Dasar tahun 1945 merupakan konstitusi, sebagai hukum dasar sekaligus merupakan bukti adanya pembaharuan hukum di Indonesia, yang semula bernama Hindia Belanda, yang sudah seharusnya mempunyai tata hukum berbeda, sebagai ujud Negara yang merdeka.

Pembaharuan hukum setelah ditetapkannya UndangUndang Dasar 1945 sebagai konstitusi selalu dilakukan guna mencapai tujuan bernegara sebagaimana dirumuskan dalam alinea 4 Pembukaan Undang Undang Dasar 1945 yang menyatakan;

"Kemudian daripada itu untuk membentuk suatu Pemerintah Negara Indonesia yang melindungi segenap bangsa Indoesia dan seluruh tumpah darah Indonesia dan untuk memajukan kesejahteraan umum, mencerdaskan kehidupan bangsa,dan ikut melaksanakan ketertiban dunia yang berdasarkan kemerdekaan, perdamaian abadi dan keadilan sosial, maka disusunlahkemerdekaan kebangsaan Indonesia itu dalam suatu Undang Undang Dasar Negara Indonesia, yang terbentuk dalam suatu susunan Negara Repblik Indonesia yang berkedaulatan rakyat dengan berdasarkan kepada Ketuhanan Yang Maha Esa,Kemanusiaan yang adil dan beradab, Persatuan Indonesia dan Kerakyatan yang dipimpin oleh hikmah kebijaksanaan dalam permusyawaratan/perwakilan serta dengan mewujudkan suatu keadilan sosial bagi seluruh rakyat Indonesia ".

Dengan demikian tujuan bernegara adalah "melindungi segenap bangsa Indonesia serta tumpah darah Indonesia, memajukan kesejahteraan umum, mencerdaskan kehidupan bangsa serta ikut serta melaksanakan ketertiban dunia berdasar Pancasila. Tujuan tersebut tentu membutuhkan tata hukum, tata urutan yang 
diimplementasikan dalam pembaharuan hukum Indonesia termasuk diantaranya Pembaharuan dalam Hukum Pidana.

Hukum Pidana merupakan salah satu bagian hukum, yang penegakannya dilakukan oleh Kekuasaan Kehakiman yang dalam Undang Undang Dasar 1945 terdapat pada BAB IX Pasal 24,24A,24B dan 24C.

Pasal 24 menyatakan sebagai berikut :

(1) Kekuasaan kehakiman merupakan kekuasaan kekuasaan yang merdeka untuk menyelenggarakan peradilan guna menegakkan hukum dan keadilan.

(2) Kekuasaan Kehakiman dilakukan oleh sebuah Mahkamah Agung dan badan peradilan yang berada di bawahnya dalam lingkungan peradilan umum,lingkungan peradilan agama, lingkungan peradilan militer, lingkungan peradilan tata usaha negara, dan oleh sebuah Mahkamah Konstitusi.

(3) Badan-badan lain yang fungsinya berkaitan dengan kekuasaan kehakiman diatur dalam undang-undang.

Ketentuan lain yang berkaitan dengan kekuasaan kehakiman terdapat pada Pasal 28D ayat (1) yang menyatakan :

"Setiap orang berhak atas pengakuan, jaminan, perlindungan dan kepastian hukum yang adil serta perlakuan yang sama di hadapan hukum".

Penegakan Hukum Pidana, yang merupakan sebagian dari Kekuasaan Kehakiman, secara substantif didasarkan pada Kitab Undang Undang Hukum Pidana (KUHP) yang berasal dari Wetboek van Strafrecht voor Nederlandsch Indie (WvS v NI),yang berlakunya berdasar Aturan Peralihan UUD 1945 (sebelum amandemen) Pasal II, yang kemudian diteruskan dengan diundangkannya UndangUndang Nomor 1 Tahun 1946 tentang Peraturan Hukum Pidana, dengan nama KITAB UNDANG UNDANG HUKUM PIDANA (KUHP) atau Wetboek van Strafrecht (WvS).

Dengan demikian, KUHP yang berlakunya berdasar Undang Undang Nomor 1 tahun 1946 harus tidak bertentangan dengan konstitusi sebagai hukum dasar, yakni UUD tahun 1945. Apabila dalam Kekuasaan Kehakiman dinyatakan merupakan kekuasaan yang merdeka untuk menyelenggarakan peradilan guna menegakkan hukum dan 
keadilan, maka penggunaan KUHP juga berorientasi pada penegakan hukum dan keadilan.

Pasal 8 ayat (3) Undang Undang Nomor 16 tahun 2004 tentang Kejaksaan menyatakan "Demi keadilan dan kebenaran berdasarkan Ketuhanan Yang Maha Esa, Jaksa melakukan penuntutan dengan keyakinan berdasar alat bukti yang sah".

Pasal 2 ayat (1) Undang Undang Nomor 48 tahun 2009 tentang Kekuasaan Kehakiman menyatakan: "Peradilan dilakukan demi keadilan berdasarkan Ketuhanan Yang Maha Esa".

Pasal 5 Undang Undang Nomor 48 tahun 2009 tentang Kekuasaan Kehakiman menyatakan: "Hakim wajib menggali dan memahami nilai-nilai hukum dan rasa keadilan yang hidup dalam masyarakat".

Pasal 1 ayat (1) KUHP menyatakan bahwa: "Tidak ada suatu perbuatan dapat dipidana kecuali atas kekuatan aturan pidana dalam perundang-undangan yang telah ada,sebelum perbuatan dilakukan. Ketentuan ini lazim disebut ketentuan tentang "asas legalitas".

Dengan demikian, apabila ketentuan tentang perbuatan yang dapat dipidana digabungkan berdasar peraturan perundangan dapat disimpulkan hal-hal sebagai berikut:

1. Perbuatan yang dapat dipidana adalah perbuatan yang dilarang oleh Hukum Pidana.

2. Perbuatan tersebut bertentangan dengan nilai-nilai hukum dan rasa keadilan yang hidup di masyarakat.

3. Perbuatan tersebut bertentangan dengan keadilan berdasar Ketuhanan Yang Maha Esa.

Dengan demikian, Hakim dalam memutuskan suatu perkara harus;

1. Berlandaskan keadilan berdasar Ketuhanan Yang Maha Esa.

2. Perbuatan yang dilakukan bertentangan dengan hukum tertulis (undang-undang).

3. Bertentangan dengan hukum yang hidup di masyarakat ("theliving law").

Hakim dalam memutus perkara tidak sekedar "yuridis normatif, namun juga "yuridis cultural dan yuridis religius". Hakim dalam memutus perkara tidak dapat semata-mata 
menggunakan KUHP yang merupakan peninggalan kolonial, namun KUHP yang digunakan tersebut harus tidak bertentangan dengan Undang Undang Dasar tahun 1945 sebagai hukum dasar (konstitusi), yang didalamnya terdapat Pancasila yang merupakan cita hukum, yang menurut Hans Kalsen dinamakan "ground norm".

Friedman menyatakan, bahwa hukum sebagai suatu sistem terdiri atas 3 sub sistem, yaitu substansi hukum, struktur hukum dan cultur hukum. Sub sistem-sub sistem tersebut saling berkaitan dalam penegakan hukum. Penegakan Hukum akan berjalan baik bila ketiga sub sistem tersebut baik. Demikian pula sebalikya, apabila antara sub sistem terjadi masalah, maka penegakan hukum juga akan bermasalah. Sementara itu Philip dan Nonet menyatakan, bahwa pada perkembangannya Hukum terbagi atas 3 (tiga) klasifikasi,y aitu hukum yang represif, hukum yang otonom dan hukum yang responsip.

Kasus mbah Minah yang diputus bersalah oleh Hakim telah melakukan pencurian dan dijatuhi pidana penjara selama 1 bulan 15 hari dengan masa percobaan 3 bulan, mendapat reaksi masyarakat luas, karena dipandang pemidanaan terhadap mbah Minah melukai rasa keadilan masyarakat. Kasus mbah Minah secara singkat diuraikan sebagai berikut :

MINAH ( 55 tahun), warga Damakradenan Ajibarang Banyumas,mengambil 3 (tiga) biji kakao (buah coklat) senilai Rp.2.100,00 dari perkebunan PT Rumpun Sari Antan yang berada berdampingan dengan kebun tempat dia sedang bekerja, dengan maksud digunakan sebagai bibit. Setelah 3 (tiga) biji kakao tersebut diambil, lalu diletakkan di samping pagar pembatas kebun, lalu melanjutkan pekerjaannya berkebun.

Belum sempat biji kakao tersebut dibawa pulang, seorang mandor perkebunan bernama Sutarno menegurnya, siapa yang mengambil dan meletakkan biji kakao di samping pagar perkebunan biji kakao ?. Minah menjawab bahwa dia yang mengambil dan akan dibuat sebagai bibit. Sutarno mengatakan bahwa hal tersebut tidak boleh dan membawa 3 (tiga) biji kakao tersebut.

Dialog antara mbah Minah dan mandor Sutarno ditayangkan oleh SCTV sebagaimana diceritakan oleh mbah 
Minah pada saat diwawancarai sebagai berikut; Mandor bertanya kepada saya,"ini untuk apa Bu ?". Saya jawab: "untuk bibit...". Dia melarang, saya bilang,"ya sudah, kalau tidak boleh......". Bibit kemudian dibawa pak mandor, lalu saya pulang...".

Permintaan maaf dari mbah Minah ternyata tidak diterima, manajemen PT Rumpun Sari Antan justru melaporkan mbah Minah ke Kepolisian Sektor Ajibarang Banyumas pad akhir bulan Agustus 2009. Laporan berlanjut dengan penyidikan, penuntutan dan proses di Pengadilan Negeri Banyumas .

Pengadilan Negeri Banyumas pada tanggal 18 November 2009 mengeluarkan vonis, mbah Minah bersalah melakukan tindak pidana pencurian, dengan pidana 1 bulan 15 hari penjara, dengan masa percobaan 3 bulan. Setelah vonis selesai dibaca, pengunjung sidang beramai-ramai menemui mbah Minah, dan secara spontan mengumpulkan uang untuk transport pulang mbah Minah. Jaksa Noor Hani'ah pun memberikan uang transport pulang. Hakim Muslich Bambang Luqmono yang memimpin sidang, justru menemui mbah Minah, sambil meneteskan air mata mendekati dan menyalami dan mencium tangan mbah Minah.

Hakim Bambang pada saat diwawancarai wartawan berpendapat, bahwa bahwa kasus seperti ini mestinya tidak perlu sampai disidangkan di Pengadilan. Ia minta diselesaikan secara kekeluargaan. Jaksa Penuntut Umum, Noor Hani'ah menyatakan, pihaknya tidak bisa menghentikan kasus ini karena berkas perkara yang dilimpahkan dari Kepolisian sudah lengkap.

Kasus mbah Minah, yang merupakan kasus sederhana di suatu daerah terpencil, ternyata mampu menarik perhatian masyarakat luas termasuk Aparat Penegak Hukum di tingkat pusat, antara lain Menteri Hukum dan Perundang-undangan Republik Indonesia, karena seakan terjadi perbenturan antara "kepasian hukum" yang menyatakan mbah Minah bersalah dan dijatuhi pidana 1 bulan 15 hari penjara dengan masa percobaan 3 bulan, dengan rasa keadilan terbukti dengan respon masyarakat termasuk Jaksa Penuntut Umum dan Hakim pemutus perkara, yang secara spontan memberi bekal pulang kepada 
mbah Minah bahkan Hakim pemutus perkara menyalami sambil mencium tangan terpidana.

Sehubungan dengan hal tersebut, kasus ini cukup menarik untuk dibahas, dengan diberikan judul : "Implementasi asas kepastian hukum yang berkeadilan berdasar Cita Hukum Bangsa (kajian Putusan Pengadilan Negeri Banyumas tentang kasus mbahMinah)".

Kasus mbah Minah tersebut akan dikaji melalui teori hukum sebagai berikut ;

1. Teori Sistem Hukum dari Friedmann.

Sistem Hukum ("the legal system") terdiri atas substansi hukum ("legal substance"), stuktur hukum ( "legal structure") dan budaya hukum ("legal culture").

2. Tipologi Hukum dalam masyarakat dari Philippe Nonet dan Philip Selznick.

Philippe Nonet dan Philip Selznick menggolongkan tipologi hukum yang ada di masyarakat menjadi 3 golongan yakni : hukum yang represip,hukum yang otonom dan hukum yang responsip.

Philippe Nonet dan Philip Selznick menyatakan sebagai berikut :

"(1) Law as the servant of repressive power ; (2) Law as a differentiated institution capabel of taming repression and protecting its own integrity and (3) Law as a facilitation of response to social need and aspirations". (Esmi;halaman 50).

3. Stufenbou theorie dari Hans Kalsen.

"Grundnorm/Basic norm"adalah the source of identity and as the source of unity of legal system". (Esmi;halaman 44).

Grundnorm/basic norm atau cita hukum harus dipahami sebai dasar atau sekaligus pengikat dalam pembentukan perundang-undangan.

Grundnorm/basic norm atau cita hukum inilah yang akan mendasari pembentukan konstitusi (Undang Undang Dasar),sedangkan Undang Undang Dasar merupakan aturan dasar yang mendasari peraturan perundang-undangan .

\section{B. PERMASALAHAN.}


Implementasi Asas Kepastian Hukum yang Berkeadilan...

Berdasar latar belakang tersebut, dirumuskan permasalahan sebagai berikut:

1. Mengapa Hakim memutus mbah Minah telah bersalah melakukan pencurian sehingga dijatuhi pidana?

2. Bagaimana seharusnya kasus mbah Minah tersebut diputus berdasar kepastian hukum yang berkeadilan sesuai dengan cita hukum bangsa?

3. Bagaaimanakah seharusnya pengaturan asas kapastian hukum yang akan datang dirumuskan dalam Pembaharuan KUHP sehingga sesuai dengan citahukum bangsa?

\section{PEMBAHASAN MASALAH}

1. Hakim memutus mbah Minah bersalah melakukan Tindak Pidana Pencurian sehingga dijatuhi Pidana.

Aliran positivis menyatakan bahwa hukum sama dengan Undang-undang.Salah satu penganut aliran positivisme adalah John Austin yang menyatakan bahwa hukum merupakan suatu perintah (command) dari pemegang kekuasaan untuk mengatur masyarakat.Kitab Undang Undang Hukum Pidana (KUHP) dengan demikian merupakan kitab undang undang yang mengatur tetntang tindak pidana dan sanksi bagi pelanggarnya.

Penegakan Hukum ("law enforcement") dalam Hukum Pidana dilakukan oleh Sistem Peradilan Pidana ("Criminal Justice System") yang berjalan terpadu sehingga proses peradilan pidana diberi istilah "Sistem Peradilan Pidana Terpadu" ( "Integrated Criminal Justice System") yang terdiri atas lembaga kepolisian yang mempunyai kewenangan penyidikan, lembaga kejaksaan dengan kewenangan penuntutan" $\backslash$, lembaga pengadilan dengan kewenangan mengadili serta lembaga pemasyarakatan sebagai pelaksana ekseskusi.

Kewenangan setiap lembaga secara terjabar diatur dalam Kitab Undang- Undang Hukum Acara Pidana (KUHAP), yakni;

1. Kepolisian sebagai lembaga "penyelidik dan penyidikan".

2. Kejaksaan sebagai lembaga "penuntut perkara". 
3. Pengadilan sebagai lembaga "mengadili".

4. Lembaga Pemasyarakatan sebagai lembaga "pelaksana eksekusi".

Hakim memutus (memberi vonis) kepada mbah Minah telah melakukan tindak pidana pencurian dan menjatuhkan pidana 1 bulan 15 hari dengan masa percobaan 3 bulan berdasar Pasal 1 ayat 1 KUHP dan Pasal 362 KUHP.

Pasal 1 ayat 1 KUHP yang biasa disebut sebagai implementasi asas kepastian hukum (legalitas) menyatakan :

"Tiada suatu perbuatan dapat dipidana kecuali atas kekuatan aturan pidana dalam perundang-undangan yang telah ada, sebelum perbuatan dilakukan".

Hakim, demikian juga penyidik dan jaksa penuntut umum memahami Pasal 1 ayat (1) KUHP sebagai "lex scripta", yakni kepastian hukum adalah sebagaimana adanya yang tertulis dalam rumusan undang undang; sebagai "lex stricta", bahwa kepastian hukum adalah sebagaimana secara jelas dan ketat dirumuskan dalam undang undang; juga "lex certa", yakni kepastian hukum itu adalah peraturan yang dirumuskan secara pasti, cermat dan rinci, tidak boleh ada penafsiran apapun juga.

Pasal 362 KUHP menyakan :

"Barangsiapa mengmbil barang sesuatu,yang seluruhnya atau sebagian kepunyaan orang lain, dengan maksud dimiliki secara melawan hukum, diancam karena pencurian, dengan pidana penjara paling lama lima tahun atau denda paling banyak enam puluh rupiah".

Mbah Minah jelas telah mengambil biji kakao yang bukan miliknya, yakni milik PT Rumpun Sari Antan. PT Rumpun Sari Antan tidak merelakan mbah Minah mengambil biji kakao tersebut, dan melaporkan kasus tersebut ke Kepolisian. Secara tekstual dan nomatif perbuatan mbah Minah memenuhi unsur unsur pencurian yang dirumuskan dalam Pasal 362 KUHP, sehingga Hakim memidana 1 bulan 15 hari penjara dengan masa percobaan 3 bulan. Pidana 1 bulan 15 hari penjara dijatuhkan juga masih dalam batasan 
penjatuhan pidana penjara yang ditentukan dalam Pasal 362 KUHP yang memberikan batasan maksimal 5 tahun.

Pidana percobaan dijatuhkan berdasarkan ketentuan dalam Pasal 14a KUHP yang menyatakan :

“(1) Apabila Hakim menjatuhkan pidana penjara paling lama satu tahun atau kurungan, tidak termasuk kurungan pengganti,maka dalam putusannya dapat memerintahkan pula bahwa pidana tidak usah dijalani,kecuali jika dikemudian hari ada putusan hakim yang menentukan lain, disebabkan karena terpidana melakukan suatu perbuatan pidana sebelum masa percobaan yang ditentukan dalam perintah tersebut habis, atau terpidana selama masa percobaan tidak memenuhi syarat khusus yang mungkin ditentukan dalam perintah itu."

Penjatuhan pidana percobaan 3 bulan berdasar Pasal 14 b yang menyatakan "

"(1) Masa percobaan bagi kejahatan dan pelanggaran yang tersebut dalam pasal 492,504,505,506 dan 536 paling lama adalah tiga tahun dan bagi pelanggaran lainnya paling lama dua tahun".

Mbah Minah dijatuhi pidana 1 bulan 15 hari penjara, berarti sesuai dengan ketentuan yang dirumuskan pada Pasal 14 a, yang menyatakan pidana penjara paling lama 1 tahun dapat dikenakan pidana percobaan. Sedangkan lamanya pidana percobaan 3 bulan sesuai dengan ketentuan dalam Pasal $14 \mathrm{~b}$ yang menyatakan bahwa lamanya pidana percobaan untuk kejahatan (pencurian adalah tindak pidana kejahatan) adalah 3 tahun.

Kasus mbah Minah ini,walau merupakan kasus kecil yang terjadi di desa terpencil, namun ternyata mendapat tanggapan dari masyarakat luas dari segala lapisan, termasuk Aparat Penegak Hukum, karena dipandang terjadi "benturan antara kepastian hukum dengan keadilan". Juga terjadi perbenturan kepentingan antar kelas yang ada di masyarakat, antara kelas atas dalam hal ini PT Rumpun Sari Antan dengan kepentingan kelas bawah, kelas rakyat jelata dalam hal ini mbah Minah. Pada kasus ini "hukum" ditugasi untuk menyelesaikan "kepentingan" kelompok yang berbeda. 
Sistem Peradilan Pidana ("Criminal Justice System") melakukan tugasnya, dengan memproses kasus ini mulai dari penyidikan yang dilakukan oleh penyidik, dalam ini Polsek Ajibarang, dilkukan penuntutan oleh Jaksa Penuntut Umum, dalam ini Kejaksaan Negeri Bamyumas, dan Pengadilan Negeri Banyumas memeriksa dan mengadili perkara ini. Lembagalembaga tersebut melaksanakan tugasnya sesuai dengan ketentuan yang terdapat pada Kitab Undang Undang Hukum Acara Pidana (KUHAP), dan pada akhirnya Hakim memutuskan (memberi vonis) mbah Minah bersalah.

Pada peristiwa ini tampak, bahwa Aparat Penegak Hukum dalam Sistem Peradilan Pidana, sebagaimana teori yang dikemukakan oleh Philippe Nonet dan Philip Selznick memposisikan hukum pada posisi "Hukum yang Otonom". Hukum yang Otonom mempunyi ciri setia menjaga kemandirian hukum itu sendiri, dalam hal ini adalah aturan hukum pidana yang terdapat pada KUHP. Karena sifatnya yang mandiri, maka legitimasi hukum terletak pada keutamaan prosedural hukum yang bebas dari pengaruh apapun, termasuk politik. Adanya pembatasan prosedur yang sudah mapan, dalam hal ini sebagaimana telah diatur dalam Kitab Undang Undang Hukum Acara Pidana (KUHAP). Hukum Otonom tidak akmodatif terhadap perkembangan dan dinamika sosial yang terjadi di masyaraka, sehingga sering kurang dirasa memberi keadilan substantif yang dibutuhkan oleh masyarakat, yang oleh Paul Scholten dikatakan bahwa justru pada hukum dan kepastian hukum diperoleh "keadilan". Yang diperoleh dari Hukum Otonom adalah "keadilan prosedural" bukan "keadilan substantif".

Philippe Nonet dan Philip Selznick menyatakan tentang Hukum Otonom sebagai berikut;

"Gagasan bahwa "prosedur" merupakan jantung dari hukum menempati sisi penting dalam etos "hukum otonom". Penjinakan represi dimulai dengan tumbuhnya komitmen untuk memerintah berdasarkan peraturan; pada gilirannya,prosedur merupakan jaminan paling nyata dari suatu penerapan peraturan secara adil. Otoritas yang 
berpotensi represif dikendalikan oleh "Due process".Dalam menyelesaikan pertikaian antar penduduk dan dalam penilaian klaim-klaim oleh atau melawan negara, sistem hukum menawarkan produknya yang paling nyata dan tegas : keadilan prosedural". (Hukum Responsip; halaman 74).

Hal ini sesuai dengan komentar Noor Hani'ah, Jaksa Penuntut Umum dari kasus mbah Minah yang menyatakan bahwa dirinya tidak bisa menghentikan kasusu ini, karena berkas perkara yang dilimpahkan dari kepolisian sudah lengkap. “Kejaksaan tidak bisa mengeluarkan SP3 (Surat Perintah Penghentian Penyidikan), karena seluruh berkas dan buktinya sudah lengkap.Kita hanya bisa mengeluarkan SP3 bila berkasnya tidak lengkap atau barang buktinya kurang", tuturnya. http://ppiuk.org/node/1251. Noor Hani'ah sebagai Jaksa Penuntut Umum ternyata meneruskan perkara tersebut karena secara prosedural sebagaimana diatur dalam undang-undang (KUHAP) menyatakan demikian,walau secara pribadi ia berpendirian perkara tersebut sesunguhnya tidak perlu diajukan ke Pengadilan, terbukti setelah putusan dibacakan, sebagai rasa simpatinya kepada mbah Minah ia memberikan bekal untuk pulang.

Hakim yang memimpin persidangan, Muslich Bambang Luqmono, walau ia menyatakan mbah Minah terbukti bersalah melakukan tindak pidana pencurian dan menjatuhkan pidana, namun ia berpendapat bahwa sebenarnya kasus seperti ini mestinya tidak perlu sampai disidangkan di Pengadilan. Ia berpendapat selayaknya kasus ini dapat diselesaikan secara kekeluargaan. "Saya kira akan lebih efektif bila diselesikan dengan baik-baik secara kekeluargaan. Kita sendiri,sebagai lembaga pengadilan,tidak bisa menolak menyidangkan perkaranya,karena setelah menerima berkas perkara,(majelis hakim) mau tidak mau hrus menyidangkan perkara ini", kata Bambang.

Majelis Hakim, sebagaimana dinyatakan oleh Muslich Bambang Luqmono selaku Ketua sidang memproses perkara tersebut karena undang-undang (KUHAP) mengatur demikian. Hal ini berarti secara "prosedural" kasus tersebut memang harus diperiksa, 
walau secara pribadi berpendapat hal itu tidak perlu dilakukan, karena lebih efektif diselesaaikan secara kekeluargaan. Apalagi bila dilihat dari sikap Hakim Bambang setelah vonis dibacakan yang langsung menyalami dan mencium tangan mbah Minah menunjukkan, bahwa "rasa keadilan"nya terusik, meronta, tatkala sosok mbah Minah yang lemah dan tua dihadapkan di muka persidangan, gara-gara hanya mengambil 3 biji kakao dari sebuah PT besar, yang tentu tidak akan megalami kerugian apa-apa dengan diambilnya 3 biji kakao tersebut. Apalagi pada kenyataannya biji kakao juga tidak jadi diambil mbah Minah. Namun Hakim Bambang tidak bisa menghentikan proses perkara, karena KUHAP mengatur demikian, dan hanya mampu memutus perkara sesuai dengan rasa keadilannya, yakni menjatuhkan "pidana percobaan".

Didiek Darmanto Kapuspenkum Kejaksaan Agung RI saat itu menanggapi masalah mbah Minah menuturkan, bila cukup bukti pihaknya tidak mempunyi kewenangan menghentikan penyidikan atau meminta penyidik polisi untuk tidak melanjutkan penyidikan. "Jaksa tidak punya kewenangan itu. Kalau ada koordinasi itu seharusnya sebelum penyidikan",katanya. Didiek menyatakan lebih lanjut, "Kalau dipikir-pikir yang diambil tidak sebanding dengan perkara dan biaya yang dikeluarkan untuk menangani perkara. Didiek menyatakan, bahwa ia tidak mengetahui alasan Polisi melanjutkan kasus tersebut. "Seharusnya ini ditanyakan ke Polisi, kena apa kasus seperti ini kok diteruskan.Tidak misalnya,(diselesaikan) secara kekeluargaan,".

Komentar Didiek menunjukkan,bahwa perkara tersebut memang tidak dapat dihentikan, karena, sebagaimana komentar Jaksa Penuntut Umum dan Ketua Majelis Hakim, Undang Undang (dalam hal ini KUHAP) mengatur demikian. Jadi, secara "proses" peraara tersebut memang harus berlanjut, walau dipandang dari sisi "biaya untuk proses peradilan dan kerugian yang ditimbulkan oleh substansi perkara" tidak seimbang. 


\section{Keputusan yang seharusnya dijatuhkan kepada mbah Minah berdasar Kepastian Hukum yang berkeadilan sesuai dengan Cita Hukum Bangsa.}

Masyarakat di desa Ajibarang dan sekitarnya menyatakan bahwa perbuatan mbah Minah memetik 3 biji kakao di perkebunan milik PT Rumpun Sari Antan bukan merupakan "pencurian", dan hal itu sudah menjadi kebiasaan masyarakat, misalnya mengambil daun pisang,mengambil daun pisang, memetik beberapa buah lombok, mengambil kayu rencek dan lain sebagainya. Lebih-lebih perbuatan memetik biji kakao tersebut dilakukan di siang hari secara terangterangan, dan setelah biji dipetik diletakkan begitu saja disebelah pohon kakao tempat biji tersebut dipetik.Tidak disembunyikan, tidak dibawa lari, sebagaimana lazimnya dilakukan oleh parfa pencuri bila mencuri barang. Pada saat ditanya atau ditegur mandor Sutarno, apakah dia yang mengambil biji kakao, dengan jawaban lugu di-iya-kan, tanpa ada ekspresi besalah, dan pada saat diberitahu itu tidak boleh dilakukan, diapun tidak jadi membawa biji kakao tersebut, dan bahkan dibawa pergi mandor Sutarno. Kesimpulannya mbah Minah tidak pernah merasa melakukan "pencurian". mbah Minah tidak merasa melakukan tindak pidana. mbah Minah tidak pernah merasa bersalah, atau setidak-tidaknya mbah Minah tidak merasa berslah terhdap perbuatannya. Masyarakat setempat juga memandang bahwa perbuatan mbah Minah bukan kejahatan, perbuatan mbah Minah menurut kebiasaan setempat wajar dilakukan. Jadi menurut pandangan masyarakat setempat perbuatantersebut "tidak melanggar hukum".

Pada kasus mbah Minah terdapat "perbenturan" antara "kepastian hukum" formal yang ada dalam Paasal 1 ayat (1) KUHP dengan "(kepastian) hukum" yang hidup di masyarakat. Ada perbenturan antara hukum formal (KUHP) dengan hukum yang hidup di masyarakat. Masyarakat bahkan memandang, diprosesnya mbah Minah ke ranah peradilan tidak mencerminkan "rasa keadilan masyarakat", mereka 
merasa diperlakukan sewenng-wenang oleh "fihak yang mempunyai posisi kuat"(PT Rumpun Sari Antan).

Friedmann menyatakan bahwa" Ilmu Hukum berfungsi untuk menyelesaikan problem konkrit dengan tujuan mencapai keadilan, kesetabilan dan kesejahteraan". Dari pendapat Freidmenn tersebut dapat disimpulkan bahwa hukum merupakan institusi keadilan. oleh sebab itu maka membicarakan hukum sekaligus membicarakan keadilan Menegakkan hukum berarti menegakkan keadilan". Paul Scholten menyatakan,bahwa ilmu hukum adalah ilmu tentang keadilan, sehingga dapat disimpulkan bahwa "kepastian hukum" pada dasarnya untuk menegakkan "keadilan". Pompe menyatakan bahwa "hukum" adalah kepercayaan. Dengan demikian maka "penegakkan hukum" dimaksudkan untuk "meneguhkan kepercayaan". Sudarto menyakan bahwa hukum tidak lain merupakan kasih sayang. Menegakkan hukum adalah menegakkan "kasih sayang". Sedangkan Barda Nawawi Arief berpendapat bahwa pada "Hukum" terdapat asas "keseimbangan", keseimbangan antara kepentingan individu dan masyarakat, keseimbangan antara "kepastian" dan "keadilan, keseimbangan antara "yang formal dan yang materiel", keseimbangan antara "hukum formal"(UU) dengan "hukum yang hidup".

Menjadi pertanyaan, apakah Hakim dalam memutus perkara sudah memperhatikan "hukum yang hidup" disamping "hukum yang formal (hukum positif) atau UU"? Dari proses peradilan yang berjalan, tampak bahwa Sistem Peradilan Pidana (SPP) hanya mengacu pada "hukum postif", tidak memperhatkan "hukum yang hidup".

Undang-Undang Nomor 48 tahun 2009 tentang Kekuasaan Kehakiman, pada Pasal 5 menyatakan bahwa "Hakim wajib menggali dan memahami nilai hukum dan rasa keadilan yang hidup di masyarakat". Pada Pasal 5 tersebut secara tegas dinyatakan bahwa nilai hukum dan keadilan yang berkembang di masyarakat harus merupakan pertimbangan Hakim dalam memutus perkara. Jadi Hakim tidak cukup melandasi keputusannya hanya bertumpu pada KUHP. 
Apalagi bila di tinjau dari prespektif sejarah,KUHP berasal dari WvS NI yang berlaku pada saat pemerintahan kolonial Hindia Belanda, yang keberlakuanya berdasar rambu-rambu UUD 1945 (sebelum diamandemen), terutama Auran Peralihan Pasal I dan Undang Undang Nomor 1 tahun 1946 jo UU Nomor 73 tahun 1958, yakni WvS NI diberlakukan di Indonesia dengan ketentuan namanya diubah menjadi WvS atau KUHP,dan disesuaikan dengan suasana negara merdeka.

Dengan demikian KUHP berlaku dengan ramburambu ;

1. Tidak bertentangan dengan Pancasila yang merupakan cita hukum atau "Rechsidee/Grundnorm/Basic norm" yang menurut "Stuffenbou theorie" mendasari peraturan perundang-undangan suatu negara termasuk konstitusi/hukum dasar (dalam hal ini UUD 1945).

2. Tidak bertentangan dengan UUD 1945, sebagai "hukum dasar", terutama pasal-pasal yang berkaitan dengan "Penegakan Hukum", antara lain : Pasal 18 B, Pasal 24 ayat (1), Pasal 28 D ayat (1), dan Pasal 29 ayat (1).

3. Selaras dengan Undang Undang Nomor 48 tahun 2009 tentang Kekuasaan Kehakiman dalam kerangka pembangunan Sistem Hukum Nasional (SISKUMNAS).

Pancasila sebagai "cita Hukum" "rechtsidee"/"grundnorm/basic norm") dapat difahami sebagai konstruksi berfikir yang merupakan keharusan untuk mengarahkan hukum kepada cita-cita yang diinginkan masyarakat.

Pasal 18 B UUD tahun 1945 menyatakan:

(1) Negara mengakui dan menghormati satuansatuan pemerintahan daerahyang bersifat khusus atau bersifat istimewayang diatur dengan undang-undang.

(2) Negara mengakui dan menghormati kesatuankesatuan masyarakat hukum adat beserta hakhak tradisionalnya sepanjang masih hidup dan 
sesuai dengan perkembangan masyarakat dan prinsip Negara Kesatuan Republik Indonesia,yang diatur dalam undang-undang".

Pasal 24 ayat (1) UUD tahun 1945 menyatakan :

Kekuasaan Kehakiman merupakan kekuasaan yang merdekauntuk menyelenggarakan peradilan gunamenegakkan hukum dan keadilan

Pasal 28 D UUD tahun 1945 ayat (1) menyatakan :

Setiap orang berhak atas pengakuan, jaminan, perlindungan, dan kepastian hukum yang adil serta perlakuan yang sama di hadapan hukum".

Pasal 29 ayat (1) UUD tahun 1945: "Negara berdasar atas Ketuhanan Yang Maha Esa".

Undang-Undang Nomor 48 tahun 2009 tentang Kekuasaan Kehakiman menyatakan tentang "kepastian hukum" dan "keadilan" yang harus ditegakkan sebagai berikut :

Pasal 2; "Peradilan Negara menerapkan dan menegakkan hukum dan keadilan berdasarkan Pancasila".

Pasal 5 ayat (1); "Hakim wajib menggali,mengikuti,dan memahami nilai-nilai hukum dan rasa keadilan yang hidup dalam masyarakat".

Pasal 50 ayat (1); "Segala putusan pengadilan memuat pasal tertentu dari peraturan perundangundangan yang bersangkutan atau sumber hukum tak tertulis yang dijadikan dasar untuk mengadili".

Asas Legalitas yang mendasari Pasal 1 ayat (1) KUHP sudah seharusnya dilakukan intepretasi ulang sesuai dengan suasana Indonesia sebagai negara merdeka dengan berlandaskan Pancasila yang merupakan cita hukum, UUD tahun 1945 dan aturan perundangan lainnya, antara lain Undang Undang Nomor 48 tahun 2009 tentang Kekuasaan Kehakimansebagaimana ditetapkan dalam Sistem Hukum Nasional (SISKUMNAS).

Barda Nawaie Arief menyatakan perlu dilakukan reinterpretasi asas legalitas dalam konteks Sistem Hukum Nasional (SISKUMNAS) sebagai berikut ; 
1. Inti atau hakikat asas legalitas adalah asas tentang sumber hukum. Dalam konteks Siskumnas, sumber hukum tidak hanya sumber hukum formal (UU/Hukum Tertulis), tetapi juga Sumber Hukum Materiel (Hukum Tidak Tertulis yang hidup di masyarakat). Jadi asas legalitas tidak hanya diartikan sebagai asas kepastian hukum yang formal, tetapi juga kepastian hukum materiel, tidak hanya diartikan sebagai "nullum delictum sine lege", tetapi juga "nullum delictum sine ius".

2. Asas legalitas pada inti/hakikatnya juga mengandung asas "Lex Temporis Delicti " (LTD), yaitu seseorang hanya dapat dihukum berdasar "lex" yang ada /berlaku pada saat delik dilakukan. Dalam konteks Siskumnas, "lex" yang sudah ada pada waktu delik terjadi, bisa juga hukum yang hidup/yang berlaku di dalam masyarakat. Jadi apabila seseorang dinyatakan telah melakukan perbuatan yang bertentangan (bersifat melawan hukum) atau yang sesuai (berarti tidak bersifat melawan hukum) dengan hukum/kebiasaan yang berlaku dalam masyarakat pada saat perbuatan itu dilkukan, maka hal demikian tidak bertentangan dengan asas LTD.

3. Dalam konteks Siskumnas, asas legalitas seyogyanya tidak hanya dilihat / diartikan sebagai asas kepastian hukum ("principle of certainty ; the rule of law"), tetapi juga harus dilihat / diartikan sebagai asas keadilan ("principle of justice; the rule of justice"), sebagaimana dinyatakan oleh Douglas Husak, bahwa asas legalitas pada hakikatnya adalah asas keadilan ("the principle of justice"). Terlebih dalam Pasal 28 UUD tahun 1945 digunakan istilah "kepastian hukum yang adil". Douglas Husak menyatakan sebagai berikut : "Fidelity to law cannot be construed merely as fidelity to statutory law,but must be understood as fidelity to the principle of justice that underlie statutory law". 
Hakim yang memimpin persidangan mbah Minah waktu dimintai tanggapan tentang kasus mbah Minah menjawab sambil menahan tangis;"Tiga butir kakao sangat berarti bagi petani untuk dijadikan bibit,dan bagi perusahaan jumlah tersebut tak berarti.".

Bambang mengaku tersentuh dengan yang dialami Minah karena teringat kehidupan orang tuanya yang juga petani. Bahkan menurut Bambang, perkara nenek Minah yang dinilai kecil tersebut sudah melukai banyak orang. Patrialis Akbar, Menteri Hukum dan HAM saat itu memberi komentar terhadap kasus mbah Minah sebagai berikut: "Para Penegak Hukum harusnya mempunyai prinsip kemanusiaan ,bukan Cuma menjalankan hukum secara positivistik. "Itu saya kira sangat memalukan",(Kompleks Istana Presiden ; Medan Merdeka Utara Jakarta, jumat 20112010). "Penegak Hukum memang harus punya prinsip kemanusiaan, masak nenek-nenek begitu....Hakimnya saja sampai menangis melihat nenek itu". Patrialis berjanji akan membuat sistem yang bisa menjawab permasalahan-permasalahan seperti yang sedang dialami oleh nenek Minah, "nanti kita buat sistem...penjara sekarang kan sudah penuh ...".

Mencermati pernyataan Bambang dan Patrialis Akbar dapat disimpulkan bahwa keduanya mengakui dan merasakan bahwa membawa kasus mbah Minah melukai rasa "keadilan masyarakat". disamping pertimbangan biaya dan kerugian yang tidak seimbang.

Hal ini senada dengan pendapat Sudarto, yang menyatakan bila akan mengadakan kriminalisasi harus memperhatikan hal-hal sebagai berikut:

1. Penggunaan hukum pidana harus memperhatikan tujuan pembangunan nasional, yaitu mewujudkan masyarakat adil dan makmur yang merata materiel spiritual berdasarkan Pancasila; sehubungan dengan ini maka (penggunaan) hukum pidana bertujuan untuk menanggulangi kejahatan dan mengadakan pengugeran terhadap tindakan penanggulangan itu sendiri,demi kesejahteraan dan pengayoman masyarakat.

2. Perbuatan yang diusahakan untuk dicegah atau ditanggulangi dengan hukum pidana harus 
merupakan perbuatan yang tidak dikehendaki, yaitu perbuatan yang mendatangkan kerugian (materiel dan atau spiritual) atas`warga masyarakat.

3. Penggunaan hukum pidana harus pula memperhitungkan prinsip biaya dan hasil ("cost and benefit principle").

4. Penggunaan hukum pidana harus pula memperhatikan kapasitas atau kemamp;uan daya kerja dari badan-badan penegak hukum,yaitu jangan sampai ada kelampauan beban tugas.("overbelasting").

Kesimpulan yang dapat ditarik dari pendapat Sudarto adalah bahwa apabila akan melakukan kriminalisasi, yaitu menjadikan suatu perbuatan menjadi "tindak pidana" hendaknya memenuhi kriteria

1. Memperhatikan tujuan Pembangunan Nasional,demi kesejahteraan dan pengayoman masyarakat.

2. Perbuatan mendatangkan kerugian,baik materiel mauun spirituil.

3. Memperhatikan "cost and benefit principle".

4. Memperhatikan kemampuan data kerja badan penegak hukum untuk menghindari "overbelasting".

Pendapat Sudarto identik dengan hasil Simposium Pembaharuan Hukum Pidana Nasional tahun 1980.

Berdasar pemikiran-pemikiran tersebut,maka seharusnya kasus mbah Minah tidak perlu bahkan tidak layak diproses dalam Sistem Peradilan Pidana karena secara substantief perbuatan yang dilakukan oleh mbah Minah bukan bersifat melawan hukum secara materiel dan bertentangan dengan rasa keadilan yang hidup dimasyarakat.

Apabila kasus mbah Minah dipandang sebagai perbuatan yang tidak melawan hukum, niscaya rasa keadilan masyarakat dapat diujudkan, karena keadilan yang ditegakkan sesuai dengan aspirasi masyarakat, yakni keadilan yang sesuai dengan "kearifan lokal" (local wisdom), sebagai ujud dari implementasi "Bhineka 
tunggal ika" yang meerupakan pangejawantahan dari Sila ke 3 Pancasila,Persatuan Indonesia". Disamping itu juga mampu mewujudkan keadilan yang "humanis", keadilan yang manusiawi, sebagai implementasi dari Sila ke 2 dari Pancasila, Kemanusiaan Yang Adil dan Beradab. Keadilan yang religius juga terwujud sebagai implementasi dari Sila pertama Pancasila,Ketuhanan Yang Maha Esa. Apabila mbah Minah tidak diproses melalui Sistem Peradilan Pidana berarti telah ditegakkan "kepastian hukum yang materiel untuk mewujudkan keadilan yang sesuai dengan cita hukum bangsa yakni Pancasila".

Apabila demikian yang terjadi, maka menurut Philippe Nonet dan Philip Selznick telah diterapkan hukum yang responsif, yang bercirikan antara lain mampu beradaptasi secara bertanggung jawab,selektif dan tidak serampangan.

"Suatu institusi yang responsif mempertehankan secara kuat hal-hal yang esensial bagi integritasnya sembari tetap memperhatikan keberadaan kekuatan-kekuatan baru di dalam lingkungannya. Untuk melakukan hal ini hukum responsif memperkuat cara-cara bagaimana keterbukaan dan integritas dapat saling menopang walau terdapat pertentangan diantara keduanya. Lembaga responsif menganggap tekanan-tekanan sosial sebagai sumber pengetahuan dan kesempatan untuk melakukan koreksi diri".( Philipe-Nonet,87).

Apabila dikaji dari penegakan sistem hukum menurut Friedmenn yang terdiri atas substansi, struktur dan kultur, maka perlu diadakan kajian substansi dan kultur lebih progrsif, yakni secara "substantief" kepastian hukum tidak hanya difahami secara formal namun hendaknya difahami secara materiel. Sifat Melawan Hukum juga hendaknya difahami secara materiel, apakah secara substantief / materiel suatu perbuatan merupakan tindak pidana apa tidak. Apabila hal ini dilakukan, maka yang diwujudkan bukan sekedar "formal justice" namun juga "substantif justice".

Secara kultural, dengan demikian, hukum yang diakui tidak sekedar hukum formal, hukum positif, 
hukum Undang Undang namun juga hukum yang hidup ditengah masyarakat.("the living law").

Anthon F Susanto berpandangan tentang keadilan sebagai berikut :

....sebuah keputusan yang adil disatu fihak memperoleh pengakuan dengan cara mengindahkan aturan,namun di lain fihak mengakui hal-hal di luar itu artinya sesuatu akan dianggap adil tidak sekedar keputusan mematuhi aturan hukum,.Sebuah keputusan akan menjadi adil apabila diambil melalui sebuah proses interpretasi hukum.Seorang hakim misalnya, pada setiap pembacaan keputusan yang menetapkan sesuatu menghasilkan yang adil apabila menjaga undang undang sekaligus menghancurkan atau menghapus undang-undang....".(Jurnal Keadilan Sosial 39-40).

Keadilan menurut Anthon F Susanto tidak sekedar sesuai dengn hukum positif,namun juga hal di luar itu dengan jalan interpretasi. Bukankah dapat disimpulkan bahwa "hal di luar itu" sebagaimana dikemukakan adalah "hukum yang hidup" ("the living law") ?.

\section{Pengaturan yang seharusnya ada pada KUHP yang akan datang tentang Kapastian Hukum yang berkeadilan sesuai dengan Cita Hukum Bangsa.}

Pengaturan "kepastian hukum" yang "berkeadilan" dalam KUHP yang akan datang dilakukan dngan melakukan Pembaharuan Hukum Pidana ("Penal Reform"). yang terdiri atas pembaharuan hukum pidana materiel (substantief), pembaharuan hukum pidana formil/hukum acara pidana, dan pembaharuan hukum pelaksanaan pidana.

Pembaharuan Hukum Pidana merupakan bagian dari Pembangunan Hukum Nasional, yang juga merupakan bagian dari Pembangunan Nasional yang bertujuan untuk mewujudkan tujuan bernegara sebagaimana dirumuskan dalam alinea 4 UUD tahun 1945 berdasarkan Pancasila sebagai cita hukum ("rechtsidee/grundnorm"). Pada dasarnya tujuan bernegara adalah mewujudkan kesejahteraan sosial dan perlindungan sosial ("social welfare dan social defance") berlandaskan Pancasila sebagai "grundnorm". 
Hukum Pidana sebagai suatu sistem, sebagaimana dikemukakan oleh Friedmann terdiri atas : substansi hukum ("legal substance"), struktur hukum ("legal structure") dan budaya hukum ("legal culture"). KUHP adalah induk dari Hukum Pidana Substantief/materiel, dan merupakan bagian dari "Substansi Hukum". Bagian lain dari "substansi hukum" adalah Hukum Pidana formil/Hukum Acara Pidana, dan Hukum Pelaksanaan Pidana.

Dengan demikian, apabila akan dilakukan Pembaharuan Hukum Pidana, maka harus diadakan pembaharuan substansi hukumnya ("legal substance reform"), pembaharuan struktur hukum ("legal structure reform") dan pembaharuan budaya hukum ("legal culture reform"). Pembaharuan hukum tersebut harus berlandaskan Pancasila sebagai "cita hukum" ("rechtsidee/grundnorm").

KUHP sebagai bagian dari substansi hukum ("legal substance") apabila hendak diperbaharui harus berlandaskan Pancasila sebagai cita hukum, yang menurut Barda Nawawi Arief berlandaskan "asas keseimbangan" ("asas monodualistis"), yakni berlandaskan keseimbangan terhadap sila-sila yang terdapat pada Pancasila, yakni terwujudnya hukum yang "religius,humanis serta sesuai dengan asas kemasyarakatan).

Pembaharuan Kitab Undang Undang Hukum Pidana (KUHP) hendaknya memperhatikan "asas keseimbangan monodualistis" berlandaskan Pancasila ,yakni antara lain

1. Keseimbangan antara "kepastian hukum" dan "keadilan" (kesimbangan antara "asas legalitas" dengan "asas culpabilitas").

2. Keseimbangan antara "kepastian hukum yang formal" dengan kepastian hukum yang substansial/materiel.

3. Keseimbangan antara diberlakukannya "hukum tertulis"/UU dengan "hukum tidak tertulis /hukum yang hidup ("living law"). 
Implementasi Asas Kepastian Hukum yang Berkeadilan...

4. Keseimbangan antara keadilan "prosedural" ("formal justice") dengan keadilan "substansial". ("substantieve justice").

5. Keseimbangan keadilan berdasarkan Ketuhanan ("religius justice"), berlandaskan kemanusiaan ("humanis justice"),keadilan berdasarkan persatuan/kebinekaan justice"),keadilan ("integralistic kerakyata keadilan berdasarkan keadilan sosial ("social justice").

6. Keseimbangan antara kepentingan pelaku tindak pidana ("offenders") dan korban tindak pidana ("victim").

7. Keseimbangan antara "pemberian sanksi" dengan "permaafan".

8. Keseimbangan antara diteruskan atau dihentikannya "proses peradilan"

Hal tersebut akan dapat terlaksana apabila aspirasi dan peran masyarakat dibuka seluas-luasnya dalam pembangunan hukum nasional,yang apabila digunakan pembagian hukum menurut Phillipe Nonet dan Philip Selznick ,menggunakan pola "Hukum Responsif"

\section{KESIMPULAN.}

1. Pengadilan Negeri Banyumas dalam memutus perkara mbah Minah memandang hukum secara "positivistik",yakni Hukum disamakan dengan Undang Undang. Asas legalitas difahami secara kaku dan tekstual ("lex certa/lex scripta"), sehingga keadilan yang dicapai sekedar "keadilan formal/prosedural" ("formal justice") belum keadilan "substansial" (substansial justice").

2. Kasus tersebut seharusnya tidak perlu diselesaikan melalui Sistem Peradilan Pidana (Criminal Justice Sistem")bila "asas legalitas" (asas kepastian hukum) difahami secara fleksibel,dengan dengan memperhatikan hukum yang hidup di masyarakat. Asas legalitas difahami secara substantif, yakni perbuatan yang dilakukan harus bertentangan dengan 
hukum (tertulis maupun tidak tertulis) bukan sekedar bertentangan dengan "hukum tertulis"/ndang Undang,dengan memperhatikan rambu-rambu SISKUMNAS dan tidak bertentangan dengan UUD 1945 serta Pancasila sebagai "cita hukum".

3. Pembaharuan Hukum Pidana ("Pnal Reform"), termasuk di dalamnya Pembaharuan Kitab Undang Undang Hukum Pidana ( KUHP) harus berlandaskan pada "asas keseimbangan" ("asas/idee monodualisme")yang pada dasarnya hukum yang diwujudkan haruslah mengandung "aspek kepastian hukum"-bukan kepastian Undang Undang,dengan aspek "keadilan". Asas legalitas dimaknai sebagai perbuatan yang melanggar hukum,bukan semata "melanggar UU". Dengan demikian akan terwujud "keadilan substansial" ("substantive justice") bukan sekedar "keadilan formal/prosedural" ("formal justice"). Kesemuanya harus berlandaskan Pancasila sebagai ""cita hukum", yakni terwujudnya keadilan yang religius, humanis, integralistik, demokratik, dan sosial.

\section{E. SARAN}

1. Aparat Penegak Hukum dalam memeahami asas legalitas yang terdapat pada Pasal 1 ayat (1) KUHP hendaknya tidak secara formal dan kaku,namun difahami dalam kerangka Sistem Hukum Nasional yang berlandaskan Pancasila sebagai "cita hukum" dan UUD tahun 1945 dan diselaraskan dengan aturan perundangan lain,yakni memahami asas legalitas secara materiel,fleksibel,dengan memperhatikan "hukum yang hidup di masyarakat" ( "the living law").

2. Keadilan yang dituju oleh hukum adalah "Keadilan berdasarkan Ketuhanan Yang Maha Esa",sebagaimana tercantum pada setiap "awal keputusan hakim". Oleh karenanya Hakim bila memutus perkara tidak sekedar "berdasar Undang Undang" sehingga hanya akan menghasilkan "keadilan berdasarkan Undang Undang",nmun juga memperhatikan dengan sungguh-sungguh bgaimana "tuntutanan Tuhantentang keadilan". Dengan demikian Hakim 
Implementasi Asas Kepastian Hukum yang Berkeadilan... dituntut untuk mewujudkan "keadilan berdasar Undang Undang/hukum tertulis,sekaligus berdasarkan ajaran/tuntunan Tuhan/hukum tidak tertulis).

3. Aparat Penegak Hukum,khususnya yang tergabung dalam "sistem Peradilan Pidana ("Criminal Justice System")hendaknya secara sungguh-sungguh memperhatikan "pola tingkah laku,budaya,kebiasaan,adat istiadat dan hukum yang hidup" masyarakat tempat mereka bertugas,sehingga "keadilan yang ditegakkan,akan benar-benar sesuai dengan "rasa keadilan masyarakat". 


\section{Buku / Jurnal}

\section{DAFTAR PUSTAKA}

Anthon S Susanto; Keraguan dan Keadilan dalam Hukum (Sebuah Pembacaan Dekonstruktif);Jurnal Keadilan,2010;Jakarta Selatan.

Barda Nawawi Arief,Pendekatan Keilmuan dan Pendekatan Religius dalam rangka Optimalisasi dan Reformasi Penegakan Hukum ;Badan Penerbit Universitas Diponegoro, 2011, Semarang. --; Kasus Minah ( Pencurian Biji Kopi / Kakao);Bahan Kuliah Program Doktor Ilmu Hukum UNDIP;2010;Semarang.

;Reinterpretasi Asas Legalitas Dalam Konteks SISKUMNAS; Bahan Kuliah Program Doktor Ilmu Hukum UNDIP;2011;Semarang.

Esmi Warasih; Pranata Hukum -Sebuah telaah Sosiologis,PT Suryandaru Utama,2005,Semarang.

Munir Fuady; Dinamika Teori Hukum,Ghalilea Indonesia,2007;Jakarta.

Paul Scholten;De Structuur der Rechswetenschap ( diterjemahkan Arief Sidharta-Struktur Ilmu Hukum);Alumni;2003,Bandung.

Philippe Nonet dan Philip Selznick;Law and Society in Transition Towars Responsive Law,Harper \& Law,1978;New York. Muttaqien); Nusamedia;2007; Bandung.

\section{Peraturan Perundang-undangan}

Undang- Undang Dasar Negara Republik Indonesia Tahun 1945.

Kitab Undang -Undang Hukum Pidana ( KUHP).

Kitab Undang -Undang Hukum Acara Pidana (KUHAP).

Undang -Undang Nomor 16 tahun 2004 tentang Kejahsan.

Undang- Undang Nomor 48 tahun 2009 tentang Kekuasaan Kehakiman. 